\title{
Anatomical Differences Between the Wood of Three Species Commercialized as "Freijó" in the Amazon Region
}

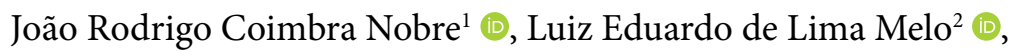 \\ Marcio Franck de Figueiredo ${ }^{2}$ (D) ${\text { Allan Motta } \text { Couto }^{3} \text { (D) Joaquim Ivanir Gomes }}^{4}$ (1) \\ ${ }^{1}$ Universidade do Estado do Pará (UEPA), Paragominas, PA, Brasil \\ ${ }^{2}$ Universidade do Estado do Pará (UEPA), Laboratório de Ciência e \\ Tecnologia da Madeira, Marabá, PA, Brasil \\ ${ }^{3}$ Universidade Estadual de Mato Grosso do Sul (UEMS), Aquidauna, MS, Brasil \\ ${ }^{4}$ Empresa Brasileira de Pesquisa Agropecuária (Embrapa), Belém, PA, Brasil
}

\begin{abstract}
This study aims to bring forward helpful anatomical characteristics to assist in the identification of Cordia goeldiana Huber, Cordia bicolor A.DC. and Cordia alliodora (Ruiz \& Pav.) Cham., all of them commercialized by the popular name of "freijo" in the Amazon region. The anatomical study of the woods followed the orientations of the International Association of Wood Anatomists IAWA Committee. The helpful wood's characteristics found to distinguish the species were: the different types of growth layers; type of axial parenchyma; presence of sheath cells involving the rays; frequency and diameter of the vessel elements; lumen diameter; and fiber wall fraction. Quantitatively, the applied multivariate techniques were helpful, once they have evidenced greater similarities between C. goeldiana and C. alliodora distinguishing themselves from C. bicolor mainly because of the rays' height $(\mu \mathrm{m})$. From the anatomical study of the woods it was possible to differentiate the species. We were able to see important anatomical patterns that could be helpful in the macroscopic and microscopic identification of the woods of C. goeldiana, C. bicolor and C. alliodora.
\end{abstract}

Keywords: wood anatomy, Boraginaceae, Cordia, Amazon. 


\section{INTRODUCTION AND OBJECTIVES}

Belonging to the Boraginaceae family, the genus Cordia was described by Linnaeus in 1753 , being an extensive taxon represented by herbs, shrubs, tropical and subtropical trees. The family has about 320 species, distributed in the tropical America, including Brazil (Stapf, 2015). According to Gomes (1982), the three most important species of the genus Cordia in America, for its wood being of commercial interest, are: Cordia alliodora (Ruiz \& Pav.) Cham., Cordia goeldiana Huber. and Cordia trichotoma (Vell.) Arráb. Ex Steud.

In the wood market of Brazilian Amazon, in its majority, the popular name of "Freijó" refers to the wood of species of the genus Cordia; however, it frequently designates only one species, C. goeldiana, which the good technological characteristics of its wood have guaranteed decades of exploration and easy commercialization in the markets of the Amazon, Brazil and around the world (Gomes, 1982; IBDF, 1978; Loureiro et al., 1979), characteristics such as: basic density between $0,55 \mathrm{~g} /$ $\mathrm{cm}^{3}$ to $0,79 \mathrm{~g} / \mathrm{cm}^{3}$, low index of linear contraction, and median values of mechanical resistance. Although C. goeldiana has predominant participation in the wood market in the Amazon region, it is likely that other species of the genus Cordia are also commercialized in the region by the name of "freijó". In the state of Rondônia, as an example, there is a probable inclusion of C. alliodora. C. bicolor is also cited in the literature as a species that is very likely to be commercialized by the same name, mostly because its wood shows similar characteristics to C. goeldiana (less resistance to cutting, good impregnation of adhesives, smooth finish surface and low defects during drying) (Dubois, 1974; Gomes, 1982; Gonçalez et al., 2010; IBDF, 1978).

In the Amazon region, the wood commercialization of different species by the same denomination is a common practice; however, while facilitating its commercialization, this practice may decrease biodiversity and contribute to the disappearance of forest species of commercial value, besides the common mistakes made in the proper application of the species. In this sense, the science of wood anatomy has shown to be an excellent alternative tool for the scientific identification of species (Muñiz et al., 2016), from wood samples devoid of vegetative material (mainly leaves, flowers and fruits) showing good degree of reliability in the results.
Based on the information above, this research aims to study and compare the wood anatomy of C. goeldiana Huber, C. bicolor A. DC. and C. alliodora (Ruiz \& Pav.) Cham. and to verify if the anatomical characters of its wood could be used to identify these species.

\section{MATERIALS AND METHODS}

For this research we used nine individuals of three species of the genus Cordia L. (Table 1). The samples were collected from the IAN wood collection, which belongs to the Embrapa Amazônia Oriental, with the respective botanic material corresponding in the IAN Herbarium. For the scientific nomenclature, we followed the List of species of the Brazilian Flora (Stapf, 2015; Tropicos, 2019).

Table 1. Studied species with its respective record number.

\begin{tabular}{lcc}
\multicolumn{1}{c}{ Specie } & $\begin{array}{c}\text { Wood collection } \\
\text { number }\end{array}$ & $\begin{array}{c}\text { Number in the } \\
\text { Herbarium }\end{array}$ \\
\hline $\begin{array}{l}\text { Cordia alliodora } \\
\text { (Ruiz \& Pav.) }\end{array}$ & 525 & IAN-48978 \\
Cham. & 527 & IAN-149847 \\
\hline $\begin{array}{l}\text { Cordia bicolor } \\
\text { A. DC. }\end{array}$ & 528 & IAN-158081 \\
& 534 & IAN-132482 \\
\hline $\begin{array}{l}\text { Cordia } \\
\text { goeldiana }\end{array}$ & 535 & IAN-132514 \\
Huber. & 557 & IAN-148039 \\
\hline
\end{tabular}

From body proofs of approximately $2 \mathrm{~cm}^{3}$, cuts were made with the help of a slide microtome (Leitz 1208) in the three usual plans of study in wood anatomy: transversal, longitudinal tangential and longitudinal radial, with thickness varying from $15 \mu \mathrm{m}$ to $20 \mu \mathrm{m}$. The histological sections were clarified with sodium hypochlorite $60 \%$, colored with a solution of hydroalcoholic safranin $50 \%$ (Sass, 1940), dehydrated in crescent ethanol series (60\%, 70\%, 80\%, 90\% and absolute ethylic alcohol), and lastly in butyl acetate (Johansen, 1940; Sass, 1940), the permanent histological slides were made in synthetic resin - Entellan ${ }^{\circledR}$.

For the measurements of the dissociated anatomical elements, a macerating solution was prepared according to the method proposed by Franklin (1945), which were colored with aqueous safranin $1 \%$, aiming the preparation 
of semi-permanent slides, confectioned with glycerin $50 \%$ (Strasburger, 1924). A light field microcopy Olympus BX51 coupled to a digital camera Evolution LC was utilized for the quantitative and qualitative anatomical characterization, as well as to obtain the images, which were analyzed in the software Image Pro - Plus (version 4.5 for Windows). Thirty measurements were fixed for each anatomical parameter evaluated. Beyond the biometric parameters commonly analyzed in wood anatomy studies, the fiber wall fraction values were also obtained, which can be determined by using the formula 100.2e/D, where (e) represents the wall thickness and (D) the total fiber diameter, the values obtained are represented as a percentage (Paula, 2005).

To analyze the data, we have run the Shapiro-Wilk test to verify the normality of the data. We have also run an analysis of variance associated with a Tukey test, assuming a level of significance of 5\%, aiming to compare the averages. Using the quantitative anatomical characters of the species, a cluster analysis and a principal component analysis (PCA) were also made. All statistical analysis were performed on the R statistical software, version 2.11.0 (R Core Team, 2008).

\section{RESULTS AND DISCUSSION}

\subsection{Anatomical characterization of the species' woods}

\subsubsection{Cordia goeldiana Huber (Figure 1)}

Macroscopic characteristics: axial parenchyma is only visible with the help of a $10 \times$ magnifying glass; it is aliform losangular shaped, vasicentric, eventually marginal; medium size pores, solitary and multiple, in the longitudinal tangential plan the rays are not stratified; growth layers in association with marginal lines.

Microscopic characteristics: vessels (pores) are diffuse, rounded and oval shaped, solitary $(83.70 \%)$, multiples of 2 (13.10\%), and multiple of 3-4 (3.20\%) medium size $(120 \mu \mathrm{m}-193.6 \mu \mathrm{m}-440 \mu \mathrm{m})$, few in number (1-3 pores $/ \mathrm{mm}^{2}, 4-8$ pores $/ \mathrm{mm}^{2}$ ); radial,
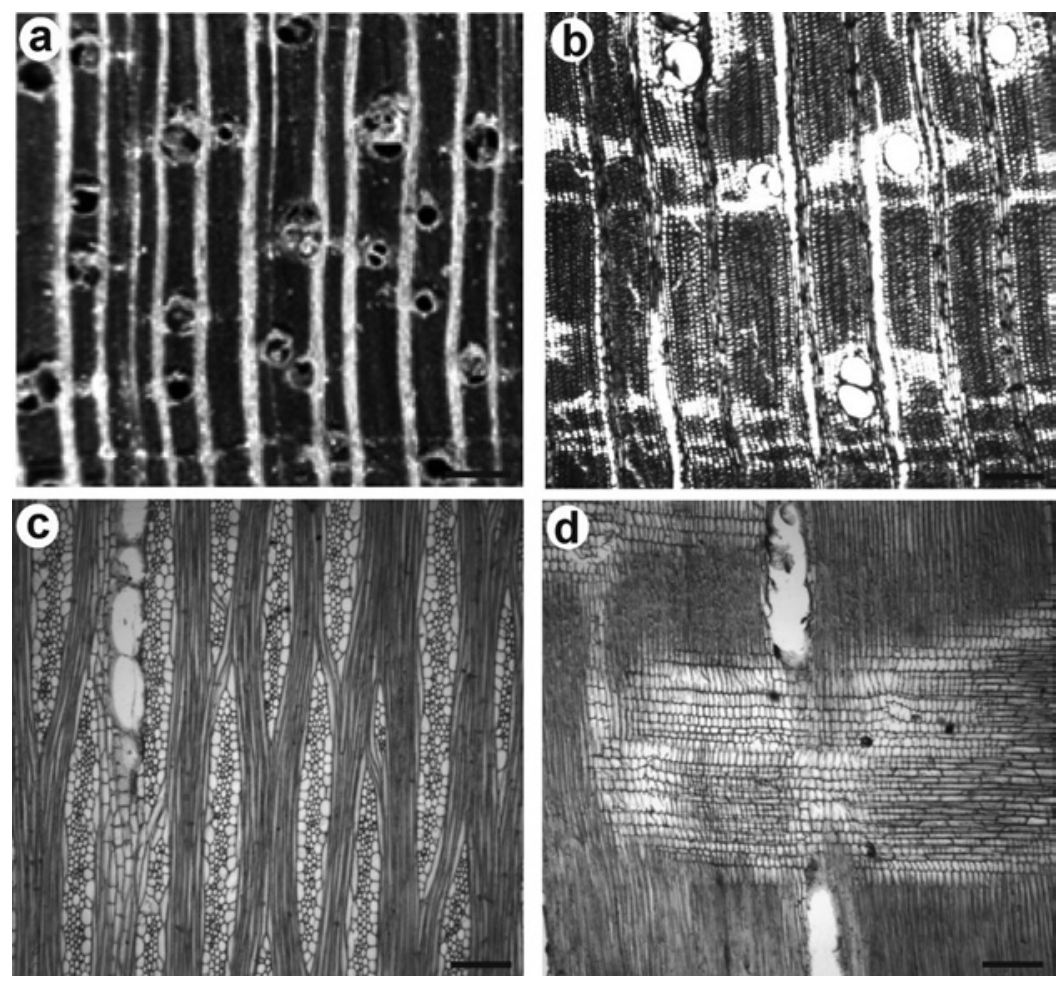

Figure 1. General characteristics of C. goeldiana's wood. a: macroscopic vision in transversal section, highlighting the scarce parenchyma, vasicentric and marginal; b-d: microscopic vision; b: transversal section, showing the solitary pores; c: tangential section, showing the non-stratified rays and sheath cells; d: radial section, highlighting the straight horizontal cells. Scale bar - a: $500 \mu \mathrm{m}$; b-d: $200 \mu \mathrm{m}$. 
tangential and racemiform disposition; circular and oval section with simple perforation plates; thyllos are occasionally found; vascular elements varying from $190 \mu \mathrm{m}$ to $620 \mu \mathrm{m}$ in length (average of $349.3 \mu \mathrm{m}$ ); very small alternate intervascular pits (average of $6.32 \mu \mathrm{m}$ ), rounded and open included; ray-vascular pits are similar to alternate intervascular. Fibers are libriform with simple pits, length varying from $650 \mu \mathrm{m}$ to $2000 \mu \mathrm{m}$ (average of $1167.20 \mu \mathrm{m}$, fiber wall thickness were classified as medium to thick). Axial parenchyma is aliform and losangular shaped, vasicentric, eventually marginal. Rays are heterogeneous with straight and square shaped horizontal cells, multi-serialized with up to eight cells width (average of 3.4 cells); height up to $2.91 \mathrm{~mm}$ (average of $1.28 \mathrm{~mm}$ ), frequency up to 3 rays/mm (average of 1.97 rays); sheath cells with full sheath.

\subsubsection{Cordia bicolor A. DC. (Figure 2)}

Macroscopic characteristics: axial parenchyma is aliform and losangular shaped, vasicentric with marginal lines, only visible with the help of a $10 \times$ magnifying glass; pores are solitary and multiple of 2, organized in dendritic arrangements; in the tangential plan the rays are not stratified; existence of growth layers in association with the marginal parenchyma.

Microscopic characteristics: vessels (pores) diffuse, oval and semi-oval, solitary (80.55\%), and multiple of 2 (19.45\%); size varying from medium to big $(110 \mu \mathrm{m}$ $219.66 \mu \mathrm{m}-280 \mu \mathrm{m})$, few in number (1-2.5-5 pores/ $\mathrm{mm}^{2}$ ); tangential disposition, racemiform and radial; oval sections with simple perforation plates; thyllos are occasionally present; vascular elements length ranging from $150 \mu \mathrm{m}$ to $630 \mu \mathrm{m}$ (average of $331.4 \mu \mathrm{m}$ ); very small alternate intervascular pits (average of $5.14 \mu \mathrm{m}$ ) with rounded and oval included openings; ray-vascular pits are similar to alternate intervascular. Fibers are libriform with simple pits, length varying from $1,128 \mu \mathrm{m}$ to $1,827 \mu \mathrm{m}$, fiber wall thickness were classified as medium to thick. Axial parenchyma is aliform and sometimes losangular and linear shaped, vasicentric and in marginal lines with up to three
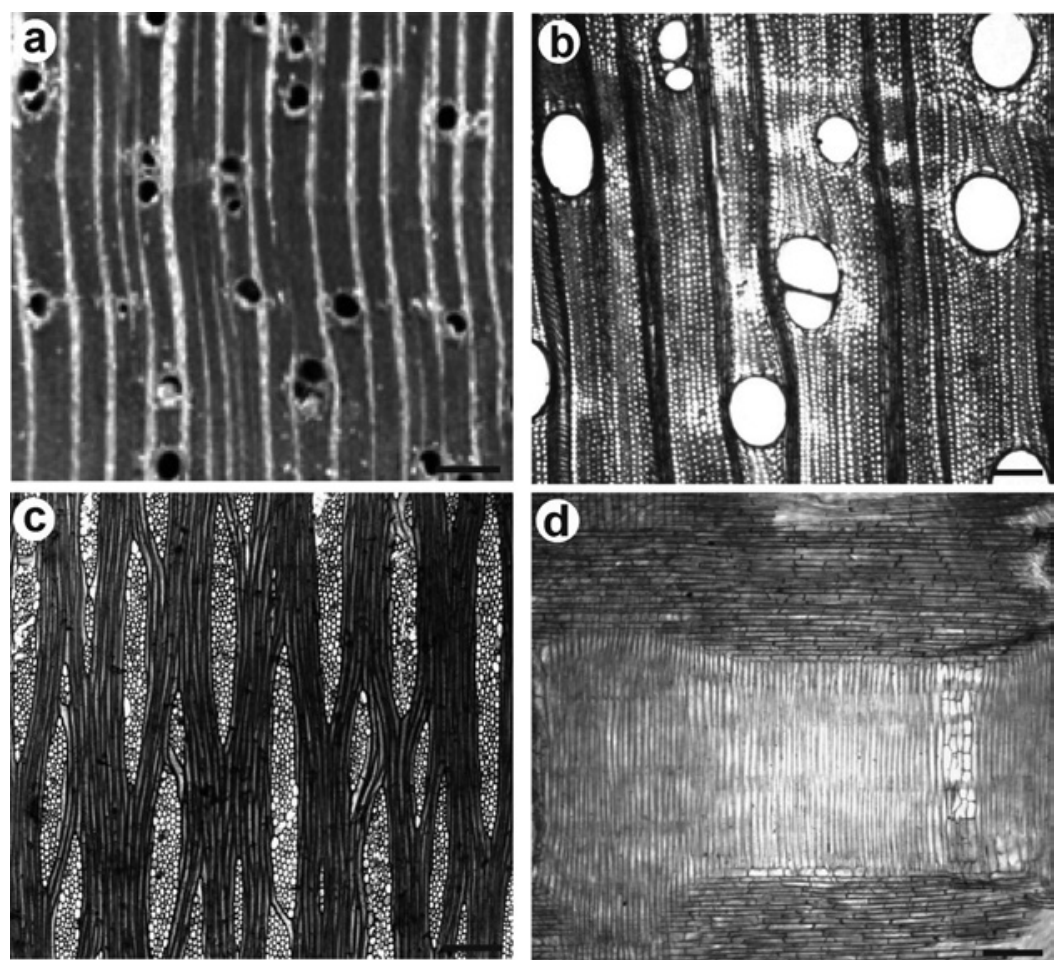

Figure 2. General characteristics of C. bicolor's wood. a: macroscopic vision in transversal section, showing the scarce aliform and vasicentric parenchyma; b-d: microscopic vision; b: transversal section, highlighting the multiple of 2 and solitary pores; c: tangential section, highlighting the non-stratified rays and poorly evident sheath cells; $\mathrm{d}$ : radial section. 
cells width; it occasionally occurs in double marginal lines. Rays are heterogeneous with straight and square shaped horizontal cells; multi-serialized rays with up to seven cells width (average of 4.4 cells); height up to $1.70 \mathrm{~mm}$ (average of $0.81 \mathrm{~mm}$ ), frequency up to three rays $/ \mathrm{mm}$ (average of 1.84 rays); sheath cells with incomplete and sparse complete sheath. Crystalline elements are frequently found in the straight and square shaped ray cells.

\subsubsection{Cordia alliodora (Ruiz \& Pav.) Cham. (Figure 3)}

Macroscopic characteristics: axial parenchyma is only visible with the help of a $10 \times$ magnifying glass, aliform and losangular shaped, vasicentric, scarce and occasionally in marginal lines; pores are predominantly solitary and multiples of 2; rays are not stratified; growth layers are very differentiable by the distribution of porous and semi porous growth rings.

Microscopic characteristics: vessels (pores) are diffuse, rounded, solitary $(84.3 \%)$, multiple of $2(13.96 \%)$ and multiples of $3-4$ pores $(1.72 \%)$; medium size $(80 \mu \mathrm{m}-135.46 \mu \mathrm{m}-240 \mu \mathrm{m})$ and few in number (1-5.7-10 pores $\left./ \mathrm{mm}^{2}\right)$; tangential, radial and racemiform dispositions; oval sections and simple perforated plates; thyllos are occasionally present; the vascular elements are short in length, varying from $250 \mu \mathrm{m}$ to $650 \mu \mathrm{m}$ (average of $407.7 \mu \mathrm{m}$ ); very small alternate intervascular pits (average of $5.14 \mu \mathrm{m}$ ), rounded with included opening; ray-vascular pits are similar to alternate intervascular. Fibers are libriform with simple pits, length ranging from $610 \mu \mathrm{m}$ to $1900 \mu \mathrm{m}$, fiber wall thickness were classified as medium to thick. Axial parenchyma is aliform and losangular shaped, vasicentric, scarce and in lines with up to three cells width. Rays are heterogeneous with straight and square shaped horizontal cells; multi-serialized rays with up to five cells width (average of 4.32 cells); height up to $2.41 \mathrm{~mm}$ (average of $1.26 \mathrm{~mm}$ ), frequency up to 3 rays $/ \mathrm{mm}$ (average of 2 rays); sheath cells with full sheath. Crystalline elements are very frequently found in the straight and square shaped ray cells.
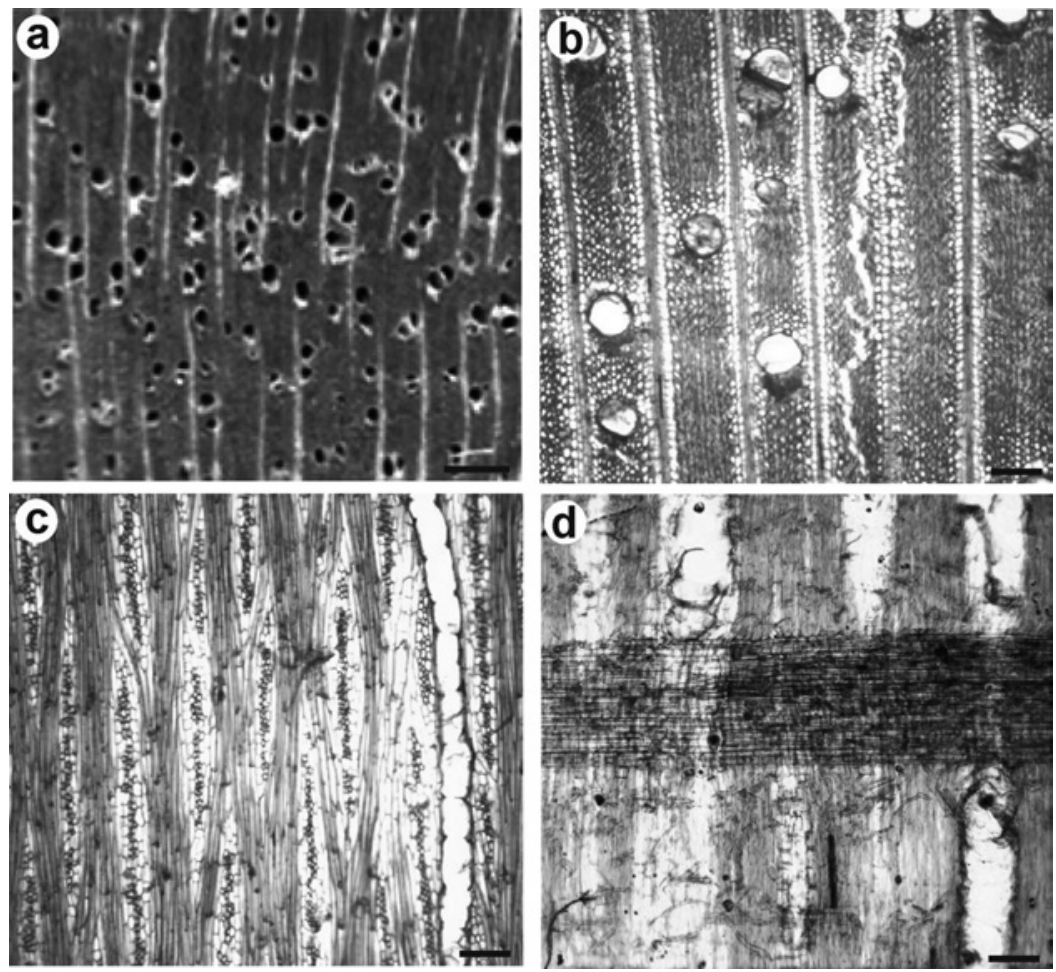

Figure 3. General characteristics of C. alliodora's wood. a: macroscopic vision in transversal section, showing the scarce parenchyma; b-d: macroscopic vision. b: transversal section highlighting the pores which are solitary in its majority; c: tangential section, showing the non-stratified rays and sheath cells; $\mathrm{d}$ : radial section evidencing the horizontal cells. 


\subsection{Anatomical differentiation of the woods}

We were able to observe that, qualitatively, the species are quite similar between themselves, with some anatomical characteristics that are better observed in histological sections of the transversal and longitudinal tangential plans (Figure 4); therefore, the qualitative and quantitative anatomical characteristics are highlighted as helpful for the differentiation of the wood's species.

Regarding the growth layers, it was commonly found the presence of distinct growth layers in the three studied species, being therefore of relevant importance, because it was possible to differentiate C. alliodora, which has growth rings distributed in semi-porous rings, from C. goeldiana and C. bicolor, which have growth rings demarcated with marginal parenchyma (Figures $4 a-4 c)$. These characteristics are of easy observation and distinction between the species studied in this research. Authors such as Gomes (1982) have characterized the growth layers of C. goeldiana as indistinct. Willians \& Léon (2003) have described the growth rings of $C$. alliodora and C. bicolor mainly with the presence of marginal parenchyma being associated with the distribution of vessels in semi-porous rings in
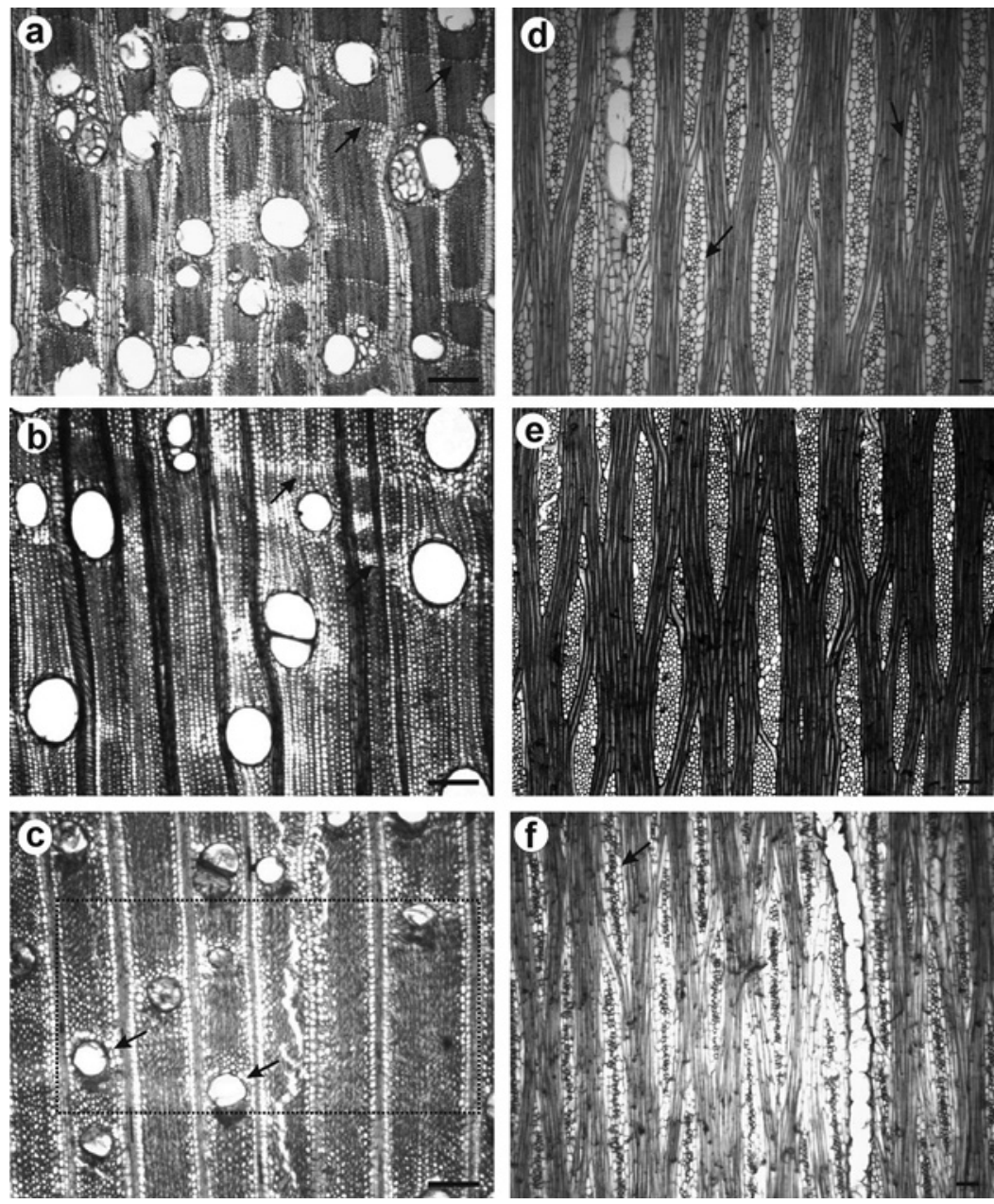

Figure 4. Qualitative anatomical differences between the studied species. a-c: transversal section (scale bar - $200 \mu \mathrm{m})$; a: C. goeldiana's axial parenchyma in marginal bands (three cells width) delimiting the growth layers (arrow); b: C. bicolar's axial parenchyma in marginal bands at the border of the growth ring, and presence of axial paratracheal aliform parenchyma (arrow); c: C. alliodora's growth layers disposed in semi-porous rings (dashed rectangle) and presence of scarce axial parenchyma (arrow); d-f: longitudinal tangential section (scale bar - $100 \mu \mathrm{m})$; d: C. goeldiana: presence of sheath cells involving the rays (arrow); e: C. bicolor: sheath cells are absent; f: C. alliodora: presence of sheath cells involving the rays (arrow). 
C. alliodora, and to thickening of the fiber walls in C. bicolor. According to Almeida (1950) and Richter \& Dallwitz (2009), the presence of growth layers in the wood of species of the genus Cordia are not always distinct. In some cases, it is possible that these growth layers are not distinguishable, which will depend on the studied taxon and also on the environment where the species is found.

Regarding the axial parenchyma, it was possible to register the presence of axial losangular aliform parenchyma, vasicentric and eventually in marginal lines in all studied species, and these characteristics were previously described by other authors (Gomes, 1982; Willians \& León, 2003). The species studied in this research have shown different types of axial parenchyma. In C. goeldiana, the axial parenchyma in marginal bands was sporadically found, and when found it was presented in very thin lines (less than three cells width), irregularly spaced. In C. bicolor, it was seen the presence of axial paratracheal aliform parenchyma of linear extension with occasional occurrence of double marginal lines. In C. alliodora, we have seen the presence of scarce parenchyma, which was easily confounded with the contour of the pores (Figure 4a-4c). Gomes (1982) has pointed out that after sheath cells, the type of axial parenchyma represents the most important characteristics for the distinction between the woods of C. goeldiana and C. bicolor. However, there is no evidence in the literature of the presence of aliform parenchyma with linear extension in C. bicolor.

As to rays, we were able to see that sheath cells with full sheath are frequent in those, both for C. goeldiana and C. alliodora, while in C. bicolor sheath cells are less frequent and sometimes incomplete (Figures $4 \mathrm{~d}-4 \mathrm{f})$. The frequency of sheath cells that completely or partially involve the rays is the main characteristic presented by Gomes (1982) for the differentiation of C. goeldiana and C. bicolor's wood and, as observed in this research, the author also describes the presence of sheath cells with incomplete sheath which is not always found in C. bicolor, while for C. goeldiana he describes its rays as predominantly associated with full sheath cells. Willians \& Léon (2003) emphasize the same characteristics that differ C. alliodora from C. bicolor. Sheath cells are defined by the Iawa Committee (1989) as cells from the radial parenchyma that are located along larger rays, which stand out from the others because they have bigger dimensions in comparison to those in the center, taller than wide, and they can partially or completely involve the ray's structure with that being a peculiar attribute of woods such as C. alliodora.

Considering the quantitative anatomy of the species studied in this research, we found out that in C. alliodora, the vessel frequency and diameter were higher and lower, respectively, when compared to C. goeldiana and C. bicolor (Table 2). The inverse relationship noticed between the frequency and vascular diameter is a pattern commonly reported in the scientific literature as an ecological tendency for species adapted to drier regions. These species generally have more frequent vessels; however, these vessels have smaller diameters, once these adaptations provide higher security in water transportation in plants subjected to stress (Arévalo et al., 2007; Chave et al., 2009; Scholz et al., 2014; Sonsin et al., 2012).

As for the rays, greater length values were noticed for C. goeldiana and C. alliodora, and greater width values for C. goeldiana. The presence of higher rays in $C$. goeldiana is described by Gomes (1982) as an important characteristic for the differentiation of this species and C. bicolor. Regarding the fiber wall fraction index, it was observed that C. goeldiana and C. bicolor have shown higher and lower values, respectively. The fiber wall fraction indicates, in percentage, the space occupied by the cell wall. This information is important by the wood technology point of view, mainly because the fiber wall thickness and its fractionated volume can positively influence the wood's basic density, which is commonly associated with the mechanical resistance of woody species (Martínez-Cabrera et al., 2009; Salmén \& Burget, 2009; Uetimane \& Ali, 2011). The presence of higher rays in C. goeldiana can also indicate a wood with better mechanical resistance properties, once recent studies have indicated a positive relationship between the height, width and ray quantity with wood's basic density and mechanical resistance, because the greater the wood's basic density, the greater will be its mechanical resistance (Salmén et al., 2009; Zheng \& Martínez Cabrera, 2013).

In the multivariate analysis, the dendrogram of similarity has classified the species in two different groups (Figure 5a). The first group includes C. goeldiana and C. alliodora, whereas C. bicolor integrates the 
second group. This arrangement in two different groups or clusters puts in evidence that even though the species belong to the same botanic genus, there are some anatomical characteristics with which we could differentiate them. The results found from the PCA have confirmed the arrangement observed in the dendrogram of similarity (Figure 5). The PCA has shown that the species' anatomical parameters fluctuated around three factors, which together explains $73.27 \%$ of the variance data. The eigenvectors and the variance explained in its latent variables are interpreted in Table 3.

The Figure $5 \mathrm{~b}$ illustrates that the principal component 1 (PC 1) was responsible for the highest variance percentage (35.62\%); and by the analysis in Table 3 it is observed that the anatomical parameter which better represents PC 1 is also the one that

Table 2. Quantitative anatomical differences (mean and standard deviation \pm ) between species.

\begin{tabular}{lccc} 
& & Species & \\
\cline { 2 - 4 } Cellular structure & C. goeldiana & C. bicolor & C. alliodora \\
\cline { 2 - 4 } Fv $\left(\mathrm{n}^{\mathrm{o}}\right.$ per $\left.\mathrm{mm}^{2}\right)$ & $3^{\mathrm{b}} \pm 1.53$ & $2^{\mathrm{c}} \pm 0.98$ & $7^{\mathrm{a}} \pm 1.85$ \\
$\operatorname{Dv}(\mu \mathrm{m})$ & $197^{\mathrm{a}} \pm 55.70$ & $207^{\mathrm{a}} \pm 82.35$ & $136^{\mathrm{b}} \pm 29.86$ \\
$\operatorname{Cv}(\mu \mathrm{m})$ & $349^{\mathrm{a}} \pm 88.38$ & $331^{\mathrm{a}} \pm 112.05$ & $408^{\mathrm{b}} \pm 106.69$ \\
$\operatorname{Piv}(\mu \mathrm{m})$ & $6^{\mathrm{a}} \pm 1.65$ & $5^{\mathrm{a}} \pm 1.49$ & $5^{\mathrm{a}} \pm 1.10$ \\
$\operatorname{Ar}(\mu \mathrm{m})$ & $1,287^{\mathrm{a}} \pm 460.91$ & $817^{\mathrm{b}} \pm 295.07$ & $1,268^{\mathrm{a}} \pm 472.14$ \\
$\operatorname{Lr}(\mu \mathrm{m})$ & $120^{\mathrm{a}} \pm 23.79$ & $82^{\mathrm{c}} \pm 24.38$ & $106^{\mathrm{b}} \pm 25.03$ \\
$\operatorname{Fr}\left(\mathrm{n}^{\mathrm{o}}\right.$ per mm) & $2^{\mathrm{a}} \pm 0.64$ & $2^{\mathrm{a}} \pm 0.55$ & $2^{\mathrm{a}} \pm 0.65$ \\
$\operatorname{Cf}(\mu \mathrm{m})$ & $1,167^{\mathrm{a}} \pm 334.39$ & $1,084^{\mathrm{a}} \pm 294.66$ \\
$\operatorname{Df}(\mu \mathrm{m})$ & $8^{\mathrm{a}} \pm 4.13$ & $11^{\mathrm{a}} \pm 3.61$ & $10^{\mathrm{a}} \pm 4.88$ \\
Epf $(\mu \mathrm{m})$ & $5^{\mathrm{a}} \pm 1.20$ & $5^{\mathrm{a}} \pm 1.31$ & $5^{\mathrm{a}} \pm 1.28$ \\
Fpf $(\%)$ & $54^{\mathrm{a}} \pm 14.01$ & $48^{\mathrm{b}} \pm 11.72$ & $51^{\mathrm{ab}} \pm 14.60$ \\
\hline
\end{tabular}

Identical letters in the same line does not differ by the Tukey test at $5 \%$ significance. Fv: vessel frequency; Dv: vessel diameter; Cv: length of the vessel elements; Piv: diameter of the intervascular pits; Ar: ray height; Lr: ray width; Fr: ray frequency; Cf: fiber length; Df: fiber lumen diameter; Epf: fiber wall thickness; Fpf: fiber wall fraction.

Table 3. Eigenvectors of the original variables in the first three principal components.

\begin{tabular}{|c|c|c|c|}
\hline \multirow{2}{*}{ Original variables } & \multicolumn{3}{|c|}{ Principal components eigenvectors } \\
\hline & PC 1 & PC 2 & PC 3 \\
\hline Vessel frequency (vessels $/ \mathrm{mm}^{2}$ ) & 0.39 & 0.21 & 0.09 \\
\hline Vessel diameter $(\mu \mathrm{m})$ & -0.29 & -0.36 & -0.20 \\
\hline Length of the vessel elements $(\mu \mathrm{m})$ & 0.18 & 0.50 & -0.19 \\
\hline Intervascular pits diameter $(\mu \mathrm{m})$ & 0.08 & -0.43 & -0.07 \\
\hline Ray height $(\mu \mathrm{m})$ & 0.44 & -0.12 & 0.12 \\
\hline Ray width $(\mu \mathrm{m})$ & 0.35 & -0.02 & $-0,34$ \\
\hline Ray frequency (rays/mm) & 0.35 & 0.19 & 0.006 \\
\hline Fiber length $(\mu \mathrm{m})$ & 0.10 & 0.12 & -0.63 \\
\hline Fiber's lumen diameter $(\mu \mathrm{m})$ & -0.35 & 0.40 & -0.16 \\
\hline Fiber wall thickness $(\mu \mathrm{m})$ & -0.09 & -0.13 & -0.58 \\
\hline Fiber wall fraction (\%) & 0.37 & -0.36 & -0.10 \\
\hline Eigenvalues & 3.92 & 2.22 & 1,92 \\
\hline Variance percentage & 35.62 & 20.20 & 17.45 \\
\hline Accumulated variance & 35.62 & 55.82 & 73.27 \\
\hline
\end{tabular}

PC: principal component. 

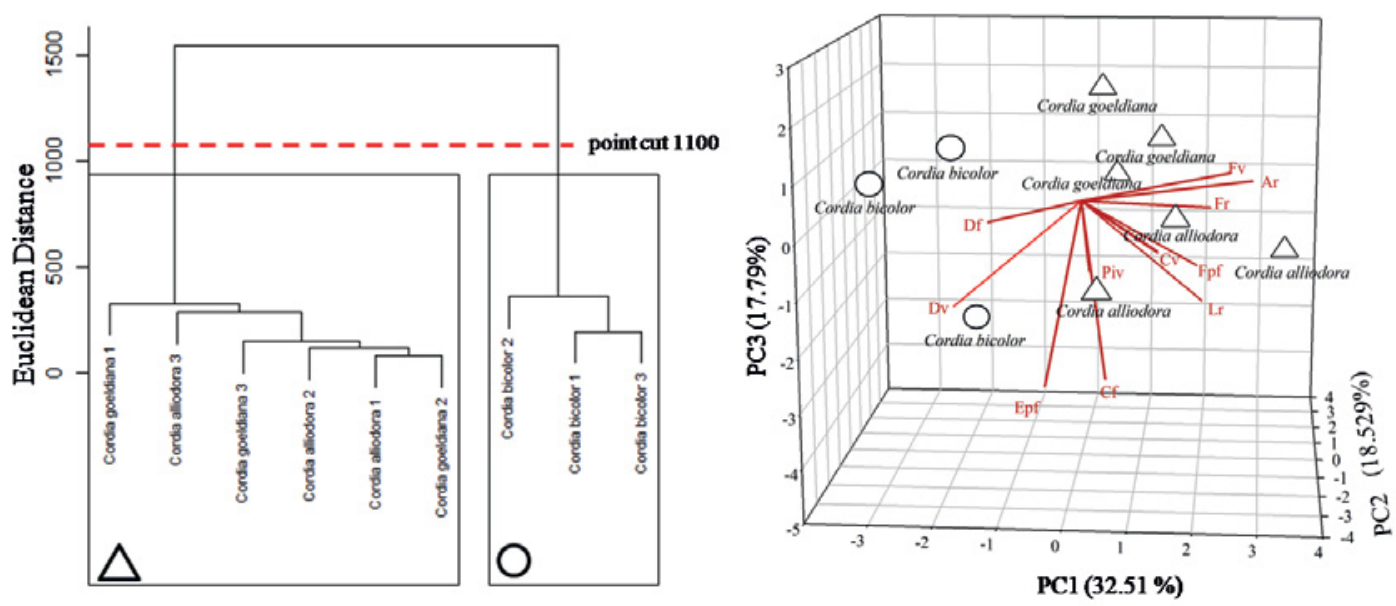

Figure 5. Overall results of the multivariate analysis. a: dendrogram obtained from the cluster analysis; b: principal component analysis (PCA). PC: principal component; Fv: vessel frequency; Dv: vessel diameter; Cv: length of the vessel elements; Piv: diameter of the intervascular pits; Ar: ray height; Lr: ray width; Fr: ray frequency; Cf: fiber length; Df: fiber lumen diameter; Epf: fiber wall thickness; Fpf: fiber wall fraction.

better explains the cluster's formation, which was the ray height $(\mathrm{Rh})$. That happened because the shadow projected in the PC 1 axis by the Rh line is the one with the highest eigenvector (0.44) among all shadows projected by the other lines (Table 3). From the joint analysis of Tables 2 and 3, it is possible to recognize that the ray height $(\mu \mathrm{m})$ is indeed the most important characteristic to differentiate C. bicolor from the others, once $\mathrm{Rh}$ is one of the few characteristics in which C. goeldiana and C. alliodora are statistically different from C. bicolor. Gomes (1982) has already indicated the same characteristic as very important in the differentiation of C. goeldiana and C. bicolor, as we have likewise observed that the rays are helpful to distinguish C. alliodora from C. bicolor.

\section{CONCLUSIONS}

From the anatomical study of the woods, we were able to differentiate the species. Important anatomical patterns were recognized and will be helpful in the process of microscopic and macroscopic identification of the woods of C. goeldiana, C. bicolor and C. alliodora.

Qualitatively, the type of axial parenchyma was essential in the distinction of the species in the macroscopy and/or microscopy. The type of growth ring observed in the study is the most important anatomical characteristic for the distinction of C. alliodora, and the morphology of sheath cells found in the rays enabled us to identify C. bicolor.

Quantitatively, the multivariate techniques applied were useful because they have evidenced greater similarity between C. goeldiana and C. alliodora, which differ them from C. bicolor mainly because of the height of the rays.

\section{ACKNOWLEDGEMENTS}

We thank the Pará State University (Uepa) and the University of Lavras (Ufla) for the structural support for this research. We also thank the Bsc. Marta César Freire Silva, research assistant in the wood collection of the Embrapa Amazônia Oriental, for the excellent work executed with vegetal microtechniques.

\section{SUBMISSION STATUS}

Received: 28 Oct., 2017

Accepted: 12 July, 2018

\section{CORREPONDENCE TO}

\section{Luiz Eduardo de Lima Melo}

Universidade do Estado do Pará, Av. Hiléia, 379, CEP 68502-100, Marabá, PA, Brasil

e-mail: luizeduardo.limamelo@gmail.com 


\section{REFERENCES}

Almeida DG. Note on a Cordia wood from eastern Brazil. Tropical Woods, New Haven 1950; 89: 48-52.

Arévalo R, Benjamin WE, Riina R, Berry PE, Wiedenhoeft AC. Force of habit: shrubs, trees and contingent evolution of wood anatomical diversity using Croton (Euphorbiaceae) as a model system. Annals of Botany 2017; 119(4): 563-579. 10.1093/aob/ mcw243

Chave J, Coomes D, Jansen S, Lewis SL, Swenson NG, Zanne AE. Towards a worldwide wood economics spectrum. Ecology Letters 2009; 12(4): 351-366. 10.1111/j.1461-0248.2009.01285.x

Dubois JLC. Prioridades e coordenação das pesquisas florestais na Amazônia brasileira. Belém: FAO; 1974.

Franklin GL. Preparation of thin sections of synthetic resins and wood-resin composites, and a new macerating method for wood. Nature $1945 ; 155(3924)$ : 51. $10.1038 / 155051 \mathrm{a} 0$

Gomes JI. A madeira de Cordia goeldiana Huber. Belém: Embrapa; 1982.

Gonçalez JC, Félix TLF, Gouveia FN, Camargos JAA, Ribeiro PG. Efeito da radiação ultravioleta na cor da madeira de freijó (Cordia goeldiana Huber) após receber produtos de acabamento. Ciência Florestal 2010; 20(4): 657-664. 10.5902/198050982424

Gottwald H. Wood anatomical studies of boraginaceae (S.I.): I. Cordioideae. Iawa Jornal 1983; 4(2-3): 161-178. 10.1163/22941932-90000409

Iawa Committee. Iawa list of microscope features for hardwood identification. IAWA Bull 1989; 10(3): 219-332.

Instituto Brasileiro de Desenvolvimento Florestal IBDF. 1978. Available from: www.ibdf.org

Johansen DA. Plant microtechnique. New York: McGraw-Hill Book Company; 1940.

Loureiro AA, Silva MF, Alencar JC. Essências madeireiras da Amazônia. Manaus: Inpa; 1979.

Martínez-Cabrera HI, Jones CS, Espino S, Schenk HJ. Wood anatomy and wood density in shrubs: responses to varying aridity along transcontinental transects. American Journal of Botany 2009; 96(8): 1388-1398. 10.3732/ajb.0800237

Muñiz GIB, Carneiro ME, Batista FRR, Schardosin FZ, Nisgoski S. Wood and charcoal identification of five species from the miscellaneous group known in Brazil as "Angelim" by Near-IR and wood anatomy. Maderas: Ciencia y Tecnología 2016; 18(3): 505-522. 10.4067/S0718-221X2016005000045
Paula JE. Caracterização anatômica da madeira de espécies nativas do cerrado, visando sua utilização na produção de energia. Cerne 2005; 11(1): 90-100.

$\mathrm{R}$ Core Team. R: a language and environment for statistical computing. Vienna: R Foundation for Statistical Computing; 2008 [cited 2019 Ago. 2]. Available from: http://www.R-project.org

Rebollar S, Quintanar A, Perez CP. Estudio anatómico de la madera de Psidium sartorianum (Myrtaceae) y Cordia gerascanthus (Boraginaceae). Acta Botánica Mexicana 1994; (27): 89-97.

Richter HG, Dallwitz MJ. Commercial timbers: descriptions, illustrations, identification, and information retrieval. 2009 [cited 2019 Ago. 2]. Available from: https:// bit.ly/31noNSL

Salmén L, Burgert I. Cell wall features with regard to mechanical performance: a review COST Action E35 20042008: wood machining - micromechanics and fracture. Holzforschung 2009; 63(2): 121-129. 10.1515/HF.2009.011

Sass JE. Elements of botanical microtechnique. New York: McGraw-Hill Book Company; 1940.

Scholz A, Stein A, Choat B, Jansen S. How drought and deciduousness shape xylem plasticity in three Costa Rican woody plant species. IAWA Journal 2014; 35(4): 337-355. 10.1163/22941932-00000070

Sonsin JO, Gasson PE, Barros CF, Marcati CR. A comparison of the wood anatomy of 11 species from two cerrado habitats (cerrado s.s. and adjacent gallery forest). Botanical Journal of the Linnean Society 2012; 170(2): 257-276. 10.1111/j.1095-8339.2012.01282.x

Stapf MNS. Cordia in Lista de Espécies da Flora do Brasil. 2015 [cited 2014 Dec. 28]. Available from: https://bit. ly/2GSdiuQ

Strasburger EA. Handbook of practical botany. MacMillan \& Company: New York; 1924.

Tropicos.org. 2019 [cited 2018 Jan. 15]. Available from: http://www.tropicos.org

Uetimane E Jr, Ali AC. Relationship between mechanical properties and selected anatomical features of ntholo (Pseudolachnostylis maprounaefolia). Journal of Tropical Forest Science 2011; 23(2): 166-176.

Willians J, León H. Anatomía de la madera de 9 especies del género Cordia L. (Boraginaceae-Cordioideae) que crecen en Venezuela. Revista Forestal Venezolana 2003; 47(2): 83-94.

Zheng JM, Martínez-Cabrera HI. Wood anatomical correlates with theoretical conductivity and wood density across China: evolutionary evidence of the functional differentiation of axial and radial parenchyma. Annals of Botany 2013; 112(5): 927-935. 10.1093/aob/mct153 